\title{
Earnings Announcement and the Performance of Security Prices of Companies Listed on the Nairobi Securities Exchange, Kenya
}

\author{
Raude John O. Messo ${ }^{1} \&$ John Byaruhanga ${ }^{2}$ \\ ${ }^{1}$ Department of Finance and Accounting, Kenya \\ ${ }^{2}$ Department of Economics, Kenya \\ Correspondence: Raude John O. Messo, Department of Finance and Accounting, Kenya. E-mail: \\ johnmesso@yahoo.com
}

Received: August 8, 2019

doi:10.5539/ijbm.v14n9p188

\begin{abstract}
Security price performance is a significant economic activity which measures the company's wealth and plays a vital role in economic growth. Security price performance reflects investor perception to earn and grow returns in the future. However, this is not the case for the NSE, Kenya N20 share index, which for the past two to three years experienced declines in security prices prompting this study to investigate the effect of Earnings Announcements on the Performance of Security Prices of companies listed on the NSE, Kenya. The study applied the Dividend Signaling Theory, the Efficient Market Hypothesis, and the Market Expectation Theory. The study used the Event Study Methodology, administered a questionnaire and schedules to collect data from 25 listed companies, and used parametric statistical techniques - the ANOVA and Regression Analysis to analyze data and test the Hypotheses. The study found Earnings Announcements were insignificant at 5 percent significant level; thus, concluded that Earnings Announcements did not affect the Performance of Securities of companies listed on the NSE, Kenya. This study will guide the market activities and provide a better understanding of how to optimize returns. It will enable the policymakers to assess and evaluate the current status and, provide a platform for making reviews, designs, and formulate policies to regulate and control trading activities on the financial markets, contribute to knowledge and strengthen the foundation for further research. Future research should investigate the effects of other events on the performance of security prices of listed companies.
\end{abstract}

Keywords: earnings announcements, performance, security price

\section{Introduction}

Security price performance is an important economic activity which measures a company's ability to increase or decrease the wealth of its shareholders and works as an indicator of the overall health of the economy. In theory, security price represents how much it costs to own a small fraction of a company and reflects investor perception of its ability to earn and grow its profits in the future. Security price performance is explained by upward and downward movement in price behavior. According to Boyes (2011), a rise in security price indicates that the market expectations are revised upward, and, more investors will want to buy the company's securities, and fewer will want to sell them. A fall in security price indicates that the market expectations are revised downward, and, fewer investors will want to buy the company's securities, and more will want to sell the same.

Security Performance according to Schwert (1990), plays a vital role in the economy through various means, such as, the security exchange which is considered a general measure of the state of the economy, through which security prices affect the real economy. According to Modigliani, (1971) proposition, a permanent increase in security prices increases the individual's wealth holdings, and therefore in the higher stable income. This proposition is supported by Bernanke and Gertler (1989) and Kiyotaki and Moore's (1997) argument of the financial accelerator by which stock prices impact output which, refers to the impact that stock prices have on firms' financial statements.

However, this is contrary to the happenings on the Nairobi Securities Exchange whose N20 share index, according to the NSE Handbook (2017), experienced declines of 21 percent per year in 2015 and 2016, and, a further 12 percent in January 2017 as shown in Figure 1.1.According to Schwert's (1990) statement on security exchange market and the general measure of the state of the economy, the decline is of great concern to investors, 
firms, and the economy as a whole, as it affects the firms' market capitalization, their total value and the country's economy. This is supported by Pearce's (1983) observation where a significant economic recovery followed an increase in security prices in the United States. Therefore, the poor performance on the NSEs N20 raises the question; is the decline in the NSE, Kenya N20 share index a result of the Events in Kenya?

\subsection{Statement of Problem}

Security price performance is an important economic activity which measures the company's ability to increase or decrease the wealth of its shareholders and works as an indicator of the overall health of the economy, and, measures the value of the firm. However, this is not the case with NSE, N20 Index. In the past, two to three years NSE N20 index experienced declines in security prices by 21 percent in 2015, 21 percent in 2016, and 20 percent in January 2017. The declines are of great concern to investors, the government, and the public at large since a decline in security prices has a negative implication on investors wealth, the value of the firm and the economy. It is on this background that this study investigated the cause of the declines by examining the effect of Earning Announcements on the Performance of Security Prices of the companies listed on the NSE, Kenya.

\subsection{Objective of the Study}

The objective of the study was to investigate the effect of Earnings Announcements on the Performance of Security Prices of companies listed on the NSE, Kenya.

\subsection{Research Hypotheses}

The study formulated and tested a null-hypothesis that:

$\mathrm{H}_{0}$ : Earnings Announcements has no significant effect on the Performance of Security Prices of the company listed on the NSE, Kenya.

\subsection{Significance of the Study}

Findings of this study are expected to be of significance to various groups of people: first, to the Market players (financial institutions, securities markets, brokers, financial analysts, economists, and investors) to guide the market activities and provide a better understanding of how to optimize returns. Two, policymakers (Capital Markets Authorities, Securities Exchanges, Central Banks and other financial regulatory agencies) to enable them to assess and evaluate the current status and, provide a platform for making meaningful reviews, designs and formulate policies to regulate and control trading activities on the financial markets. Finally, to add knowledge (scholars, researchers, and learners). The ideas presented in this study will complement the existing studies and be used as reference data in conducting new studies or testing the validity of other studies in this area, serve as a cross-reference that would give a background or an overview of future studies, contribute to knowledge and strengthen the foundation for further research.

\subsection{Limitation of the Study}

This study encountered the following limitating factors; the first limitation was non-conformity with the requirements of the study. This study targeted 65 companies listed on NSE, Kenya. However, most of the companies (62 percent) did not meet the study requirements; second, lack or missing data, and in some cases, security prices were not continuous, three, documents not dated; four, non-response to questionnaires; and five, confounding events. The study overcame these limitations by dropping companies that did not meet the requirement from the list of the target population. Thus, the researcher carried out a study on 25 companies shown in Table 1. Missing documents were overcome by using the internet to obtain the missing data and prices that were not continuous. Un dated documents were also dropped from the list since the study could not get the alternative. Confounding events were overcome by removing the company from the list.

\subsection{Assumptions of the Study}

The study made assumptions that the data collected was correct and accurate. Besides, this study assumes that the finding of this study will be a representative of the whole.

\section{Literature Review and Empirical Studies}

\subsection{Literature Review}

\subsubsection{Dividend Signaling Theory}

The Dividend Signaling Theory can be traced way back to 1961, when Modigliani and Miller (1961) claimed that firms increase dividends to convey positive information about earnings prospects. The theory was, however, brought forward by Stephen Ross in 1977 who argued that in an inefficient market, management could use dividend payment to signal important information to the market which is only known to them. If management 
increases the dividend, it signals expected a high profit, and therefore share prices will rise. Ross further argued that dividend decisions were relevant, and a firm that paid a higher dividend had a higher value.

Earlier in 1973, Ross Watts published an article "The information content of dividends". In this article, Ross concluded that dividends contain weak to no information. Three years later, in 1976, Richardson Pettit carried a similar study which concluded in favor of the Signaling theory. According to Pettit (1976), the difference between reported earnings and real long-term earnings power was significant enough, for dividends to be able to contain information about future earnings. Aharony and Swary (1980) after analyzing quarterly Dividend and Earnings Announcements, concluded that dividends and earnings were strong support for the signaling theory. Werner (2018) tested Dividend Signaling Theory in an Indonesian Capital Market using quantitative approach method of path analysis from 1995 to 2005 . The study found that the signaling theory was still relevant in influencing the movement of the share price.

Fifth Schedule of Capital Markets (Securities) (2002) requires public companies listed on the securities exchange to disclose to their stakeholders, the public, and the shareholders in particular information about their earnings. In compliance, all company listed frequently declare to their shareholders the progress of their earnings. Thus, the disclosure calls for public announcements by a listed company of their performance in the form of Earnings Announcements.

This study critiques Dividend Signaling Theory from the Modigliani and Miller hypothesis (1959) that dividend reduction conveys information that future earnings will be poor and vice-versa and the Gordon's (1962) Dividend Irrelevance Model, which states that the dividend is expected to grow when earnings are retained.

The discussion of Signaling Theory is that announcement of an increase in dividend payout is taken very positively in the market and helps to build a very positive image of the company regarding the growth prospects and stability in the future and vice-versa. Therefore, positive Earnings Announcements should be associated with good and positive expectation, while a negative Earnings Announcement is expected to generate bad and negative expectation. Thus, a neutral Earnings Announcement is expected not to influence perceived value-maximizing investors' positive and negative expectation, hence the abnormal return to being generated during the earnings.

However, the findings of Modigliani and Miller (1961), Ross (1977), Aharony and Swary (1980), Pettit (1976), and Gordon's (1962) Model give contradicting arguments about the Dividend Signaling Theory, indicating that the theory has not adequately dealt with in the Earnings Announcements and the Performance of Security Prices and Trade Volumes. Modigliani and Miller hypothesis and Gordon's (1962) Model may be true for their models. However, it may not be true in general and for the assumptions put forward. Earnings and Dividend announcements are based on a firm's earnings and dividend policy. Thus, as stated in Gordon's (1962) Dividend Irrelevance Model, the dividend is expected to grow when earnings are retained since the retained earnings are invested in profitable projects.

This theory is important in this study because it provides a signal and an in-depth understanding of the behavior of security Prices and the Trade Volumes upon public announcements of Earnings, Dividend and Profit Warnings by a company.

\subsubsection{Efficient Market Hypothesis}

The event study is founded on the principle of the Efficient Market Hypothesis. Efficient Market Hypothesis according to Regnault (1863) states that security price at all times fully reflect all available information, and therefore, it is not possible for an investor to outperform the security market since prices follow a random walk. Efficient Market Hypothesis, according to Fama et al. (1969) was developed by Fama in 1960s from the earlier theoretical developments of Regnault (1863). According to Regnault (1863), prices can only change when there is new information in the market. The premise of the Efficient Market Hypothesis is that the price of the security has intrinsic value, and is calculated by obtaining the present values of streams of future cash flows expected from a firm's assets. This, at any time, reflect all available information about the firm's current and future earnings. The prices follow a random walk; hence, investors can only earn normal returns, determined by market models such as the Capital Asset Pricing Model. The speed at which any new information resulting from an unexpected event is reflected in the price of a security is a reliable indicator of market efficiency.

Rao, (2004) states that the concept of EMH, which is based on the reflection of relevant information in market prices of the securities, was introduced by Fama in 1960s. This concept relates intense competition in the capital market to fair pricing of debt and equity securities. As such, the concept of weak-form efficient markets should reflect only past information; semi-strong form efficient markets should reflect both past and present information; 
and strong-form efficient markets should reflect both past, present, and future information. Therefore, the market is efficient in weak-form if investors cannot obtain abnormal returns by analyzing relevant historical information about the securities, rendering investment tools like filter strategy, technical analysis to be ineffective. Hence, fundamental analysis will be the only effective approach for investment management.

The market is efficient in the semi-strong form if analysis of relevant historical and current information is of no use for gaining abnormal returns, rendering filter strategy, technical analysis, and fundamental analysis not to be effective for investment management. Finally, the market is efficient in strong-form if analysis of all information; past, present, and future is of no use to gain abnormal returns. For market efficiency, the following are pre-requisite: Rationality. This is the assumption that investors in the market are deemed rational to adjust their estimates of securities prices of the company when new information is released into the market. Others pre-requisites are independent deviation and arbitrage. Independent deviation assumes that the released information to the market is incomplete; hence, the irrational investor may rely on projected future sales above rational while arbitrage is the act of exploiting situations of pricing. According to Poitras (2011), "When the estimated value is sufficiently above the market price, then this provides a potentially profitable buying opportunity, or, if the estimated value is sufficiently below the market price, this is a selling opportunity." When securities are underpriced, arbitrageurs buy them in large quantities thus bringing the prices to equilibrium and short selling overpriced substitute securities, hence obeying the law that states that at any point of time the securities will be correctly priced. These are the pillars of an Efficient Market.

Although the Efficient Market Hypothesis was formulated in the 1960s, studies are still being carried out to test the market efficiency in various securities exchanges. In one of the recent studies, Kelikume (2016), tested the efficiency of the Nigerian Stock Market, using a wavelet unit root test with different lags and other traditional random walk testing procedures, on monthly average stock price index over the sample period 1985 to 2015 . The study found that the Nigerian Stock Market was efficient and followed the random walk behavior. EMH is however criticized mainly on the market crash of October 1987. Moreover, the interpretation that the hypothesis implies that returns should be unpredictable is highly misleading.

\subsubsection{Market Expectation Theory}

Whereas the Expectation Theory has been well used to explain the term structure of interest rates, the theory can also be used in this study. As such, the theory is of great importance in understanding the behavior of securities prices upon making public Announcements of Earnings, Dividends, and Profit warnings. Market Expectation Theory according to Aswath (2012), postulates that it is not the magnitude of the earnings change that matter, but the "surprise" in the earnings, measured as the earnings change relative to expectations. As such, when a company announces its earnings, markets will react to the "news" in the announcement, but the way we measure the news has to be relative to expectations. This theory has rarely been used.

Boyes (2011), states that shareholders' value will reflect the current and expected future economic earnings of the company. Thus, it is the market expectations (buyers and sellers) of the future firm's performance that determines the price of a security. Once determined, and nothing changes, the security price will not change. The revision of expectation is what causes a rise or fall in price. According to Boyes (2011), using the Feltham and Ohlson's (1995) Abnormal Net Income Model, the market value of a firm is its book value (the current security holders' equity), plus the present value of economic profits expected to be earned in the future:

$$
\mathrm{P}_{0}=\mathrm{CBV}+\mathrm{PV}[\mathrm{EP}]
$$

Where $\mathrm{P}_{0}$ is the current security price and, PV[EP] is the present value of economic profits expected to be earned in the future. According to Boyes (2011), this model indicates that the market value goes up when the expectation of the future net income rise, that is when announced earnings exceed expectations of the future, triggering an increase in net income expectation going forward and vice versa.

Thus, Security Prices tend to rise when earnings results exceed market expectations and decline when earnings results are below market expectation. For example, a company may announce earnings, which are higher than the previous period by say 10 percent. This is improved performance compared to previous earnings but may trigger a negative price reaction since the market expectation was, say 15 percent. Thus, according to Aswath (2012), a company that reports that its earnings went up by 30 percent may be seen as delivering bad news, if investors were expecting an increase of 40 percent, and a firm that announces earnings decline of 30 percent may be providing positive information, if the expectation was that earnings would decline by 40 percent.

The market expectations can be measured using reverse DCF valuation, Asset Valuation, and Reverse Earnings Valuation. Another method widely used is the consensus between the stockbrokers on earnings estimates made 
by research analysts in the market. Since there are few or studies on Market Expectation Theory, this study argues that one of the obstacles of the theory is to determine the market expectation.

\subsection{Empirical Literature}

Theoretically, Earnings are net profits of an enterprise after deducting all expenses. Owusu, Gyau, and Amaning (2016) studied the effect of Earnings Announcement on Share Price of Manufacturing Companies on the Ghana Stock Exchange using the event study methodology on 21 days window and 60 days estimation period. The study used the Standardized Excess Return approach, which corrected for most of the challenges associated with intercompany aggregation of stocks and the Single Index and Risk-Adjusted Returns Model. The study revealed that earnings announcement did not affect the stock price. The title, the methodology, the study period, and the finding of Owusu, Gyau, and Amaning's (2016) study are similar to this study. However, the differences lie on the techniques used and the geographical location of the studies, hence the gap. Sanjay and Bijoy, (2015), examined the stock price reaction around Earnings Announcement in India in 469 sampled companies from December 2002 to December 2011 with, 37 quarterly periods. The study observed a large part of abnormal returns over an elongated event window rather than very close to the event date, and, significant post-event abnormal returns of 35 out of 37 quarters. Luke (2014), investigated the extent and pattern of abnormal returns of the Standard and Poor's 500 (S\&P 500) companies around quarterly Earnings Announcements. The findings suggest that unexpected standardized earnings were a better variable for explaining abnormal returns than the previous variables used in the literature. Besides, the findings indicated that it was important to divide companies into negative and positive earnings surprise groups.

Similarly, Mohamed (2011), studied the Effect of the Earnings Announcements on the stock prices of companies listed on the Nairobi Stock Exchange. The study observed statistically negative abnormal returns in the post, and pre-announcement was significantly above the forecasted earnings per share. Lyimo (2014) examined the relationship between stock price synchronicity and earnings quality and used earning surprise and smoothness as a proxy of earnings quality, from companies listed on Bombay Stock Exchange in BSE 500, from 2006 to 2012. The study employed a panel data regression model using pooled ordinary least squares (OLS) with standard error robust. The study found that there was a significant negative relationship between earnings surprise and stock price synchronicity. Yakubu, Akuoko, and Esumanba (2013) examined the effects of corporate Earnings Announcement on the Ghana Stock Exchange (GSE), using a sample of 19 Company Listed, selected from 57 observations of Earnings Announcements from 2009 to 2012, using event study methodology. The study findings confirmed to the findings of Aharony and Swary (1980); and the findings of Dasilas et al. (2008). The study concluded that earnings announcements do convey information to the market of which investors react accordingly. Olang and Akenga (2017) studied Effect of Earnings Announcement on Share Prices of Companies Listed on the Nairobi Securities Exchange, Kenya in 2017 using Event study Methodology, correlation analysis, and t-statistics. The study found that abnormal returns around the earnings announcements date were insignificant at 5 percent level. Muga (2014) investigated the Effect of Announcement of Earnings and Dividend on Price and Volume for Listed Non-Financial Firms at The NSE for the Period 2010-2013 using an event study methodology that adopted a descriptive survey design on a sample of 30 picked on the basis of a pre-defined criterion and conducted Analysis through the mean adjusted model and results were tested for significance using a t-test. the study found that stock volumes did not instantly react to earnings announcements.

From these studies, the Earnings Announcement can either be positive or negative depending on the performance of the company. Earnings Announcement is positive when the amount of earnings is significantly above the forecasted earnings per share, and negative when the amount of earnings is significantly below the forecasted earnings per share.

\section{Research Methodology}

\subsection{Introduction}

This chapter presents the methodological base for this study. Thus, a Philosophical Perspective, Research Design, Target Population, Census, Study Area, Data Collection, and Data Analysis are discussed.

\subsection{Philosophical Perspective}

According to Crotty (1998), research philosophy is a system of beliefs and assumptions about the development of knowledge. It is what the researcher is doing when carrying out research. Research philosophy includes assumptions about human knowledge, the realities a researcher encounters in his/her research, and the extent and ways a researcher's values influence his/her research process.

This study is anchored on positivism research philosophy founded by Auguste Comte (1798-1857) since it used 
quantifiable data and statistical analytical technique in the analysis of data. Positivism research philosophy was appropriate to achieve its objectives. Macionis and Gerber (2010) state that Positivism is a philosophical theory and that certain ("positive") knowledge is based on natural phenomena and their properties and relations.

\subsection{Research Design}

This study employed a mixed research design (a Descriptive Survey Research Design, a Causal Design and Longitudinal Research Design). A Descriptive Survey Research Design, according to Trochim, (2006), provides the glue that holds the research projects together. Also, it used to structure the research, show parts of the research project, the samples or groups, measurement, treatments or programs, and methods of assignment work together to try to address the central research questions". Descriptive Survey Research Design was appropriate to this study since it reported summary data of central tendency and dispersion, namely the mean and deviation.

The inferential statistic was appropriate to this study to make inferences about the population based on the census, that is a hypothesis and significance testing.

\subsection{Target Population}

This study targeted 25 companies listed on the NSE, Kenya that met the requirements of the study (Table 1). That is a company must have had its securities traded on the NSE, Kenya for a complete year(s) uninterrupted during the study period; two, a company must have had its securities traded on NSE, Kenya continuously during the event in question; and finally, a company must have made public announcement(s) on its, Earnings and /or Profit Warning and must have been trading at the time of Interest rate capping Announcement.

Table 1. Companies Listed on the NSE, Kenya

\begin{tabular}{|c|c|c|c|}
\hline County & Sector/Industry & $\begin{array}{c}\text { Companies listed on } \\
\text { the NSE }\end{array}$ & $\begin{array}{l}\text { Companies that met the } \\
\text { requirements of the study }\end{array}$ \\
\hline \multirow[t]{12}{*}{ Nairobi } & Banking & 11 & 11 \\
\hline & Insurance & 6 & 4 \\
\hline & Energy & 5 & 1 \\
\hline & Commercial & 11 & 4 \\
\hline & Manufacturing & 6 & - \\
\hline & Investment & 6 & - \\
\hline & Agricultural & 4 & 1 \\
\hline & Automobile & 2 & - \\
\hline & Construction & 5 & - \\
\hline & Telecommunication & 1 & 1 \\
\hline & Real Estate & 1 & - \\
\hline & Exchange Trade & 1 & - \\
\hline Mombasa & Manufacturing & 1 & - \\
\hline Machakos & Manufacturing & 1 & 1 \\
\hline Kiambu & Agricultural & 1 & - \\
\hline Kericho & Agricultural & 2 & 1 \\
\hline \multirow[t]{2}{*}{ Kakamega } & Manufacturing & 1 & 1 \\
\hline & Total & 65 & 25 \\
\hline
\end{tabular}

Source: NSE Handbook (2017).

\subsection{Census}

Since the target population was small, this study used census of 25 companies (Table 1).

\subsection{Study Area}

This study was conducted in six counties in Kenya, namely; Mombasa County, Machakos County, Nairobi 
County, Kiambu County, Kericho County and Kakamega County (Table 1).

\subsection{Data Collection}

Primary data was collected from 25 companies listed on the NSE by administering a questionnaire and obtaining collaborating information by examining records held by the company. The questionnaire used structured questions consisting of 12 questions divided into six parts; 'A,' 'B,' 'C,' 'D' 'E.' and ' $F$ '. Part $A$ of the questionnaire consisted of four questions on the general information of the company. This provided the study with the general background information of the company/respondent. Part B of the questionnaire consisted of one question that collected data on the Earnings Announcements by the companies/respondents and, the date of the Announcements. This provided this study with the dates Earnings Announcements were made by the companies. Part C and D of the questionnaire consisted of two questions that collected data on the Performance of Security Prices. This part provided this study with data on the security prices. Part E of the questionnaire consisted of two questions that collected data on the Market Factor of the company. This provided this study with data on Market share and the Age of the company during the study period. Finally, Part $\mathrm{F}$ of the questionnaire consisted of two questions on the securities held by the companies/respondents. This provided the study with information about the types of securities held by the companies during the study period and information which was used to collaborate the finding of the study.

Secondary data were collected from the NSE, Kenya, using schedules. The schedules had two parts. Part A consisted of general information of the respondent /company while Part B consisted of information relating to Security Prices and Trade Volumes. This provided the study with pre-event, Event, and post-event data on the Performance of the Security Prices.

\subsection{Data Collection Procedure}

Data collection was carried out by delivering questionnaires to the respondents. After fourteen days, the research assistants visited the respondents to collect the filled questionnaires. Where the respondent was unable to fill the questionnaires or part thereof, the research assistant assisted. This study triangulated the data using questionnaire, schedules, and interviews. The researcher then visited the NSE, Kenya, to collect data on the movement of security Prices and Trade Volumes using schedules. Further, the researcher used the internet online electronic platform to collect missing data, corporate actions, and to collaborate data collected using questionnaires. The unforeseen data collection problems were minimized by using the internet to obtain the missing data, validity checks, quality checks, and testing the assumptions.

\subsection{Validity and Reliability of Research Instruments}

This study subjected the instrument for primary data collection to Karl Pearson's Product Moment correlation coefficient formula below.

$$
\left.r=n \sum X Y-\sum X \sum Y\right) / \sqrt{ }\left(\left(n \sum X^{2}-\left(\sum X\right)^{2}\right)\left(n \sum Y 2-\left(\sum Y\right)^{2}\right)\right)
$$

Where: $r=$ reliability coefficient

$\mathrm{n}=$ number of respondents

$\mathrm{X}=$ total score of the test administration

$\mathrm{Y}=$ total score of the retest administration

Reliability was expressed as a coefficient with values between zero and one; where zero indicates no reliability and one indicates perfect reliability. The reliability test revealed a coefficient of 0.7 , implying reliability was strong.

However, this study did not validate the instrument for secondary data since they are already published. Instead, the study validated data by checking the consistency of the datasets and by evaluating: the data provider's purpose, the data collector, time when the data was collected, how the data was collected, the type of data collected and whether the data relates to the area of study. Besides, the researcher made a judgment of a good fit between the research objectives and the dataset. According to Sunjoo and Erika (2013), a sound conceptualization of the research questions and a good fit between the research questions and the dataset are prerequisites to yielding valuable results.

\subsection{Data Analysis and Presentation}

This study analyzed data using the Analysis of Variance (ANOVA) technique and presented the results using tables and graphs. Before analyzing data, this study checked the six assumptions of ANOVA by running normality and homogeneity of variances tests in addition to observing the other four assumptions namely; the 
dependent variables assumption, the independent variables assumption, the independence of observations and no significant outliers' assumptions. Finally, the study carried out null hypotheses significance tests to infer the results and to draw conclusions.

Further, this study used the Event Study Methodology. In applying Event Study Methodology, this study first identified the exact dates of the event announcements. This exercise was done by examining records, publications, and the financial statements of the companies and collaborated by using internet online electronic platform and information obtained from the respondents. This was followed by dropping confounding Events to remove noise by, excluding all events that occurred together with the defined event. This study then composed the Event list and retrieved assets. The Event list in this study was designed to include information from the company relating to the Event date, the company's name, and the company identifier. The company identifier enabled this study to retrieve asset price data from the companies to run the event study and identify the normal market reaction to the determined events. Thus, this study determined: the estimation window to 200 trading days ending 20 days before event day, the event day and estimation window to 41 trading days $(-20+20)$ and the post-event window to 200 days preceding the event window.

This study then computed the returns, the mean returns, the expected market mean returns using the CAPM model, and abnormal returns from the collected data. The study then ran significant tests to determine whether the announcements triggered reactions in the security prices at 5 percent significant level. Thus $p$-value above .05 implies that the effect of the announcement was insignificant while p-value less than .05 meant that the effect of the announcement was significant.

\section{- Abnormal Returns}

Abnormal return is the unexpected excess return brought about by a particular event. This study calculated abnormal returns as a crucial measure that isolate the effects of the events from other general market factors, using the following formula:

- Security return

$$
\mathrm{R}=\frac{\mathrm{P} 1-\mathrm{P} 0}{\mathrm{P} 0}
$$

Where:

$\mathrm{R}$ is the return of company at time $\mathrm{T}$.

$\mathrm{P}_{\mathrm{i}}$, is the actual price of company at time $\mathrm{T}_{1}$

$\mathrm{P}_{0}$ is the actual price of company at time $\mathrm{T}_{0}$.

- The Capital Asset Pricing Model

This study applied the Capital Asset Pricing Model (CAPM). According to Treynor and Jack (2012), CAPM was formulated by Treynor in 1961 and 1962, Sharpe in 1964, Lintner in 1965 and Mossin in 1966 to calculate the expected returns E[R]. This model was built on the earlier work of Harry Markowitz on diversification and modern portfolio theory. It is a two-factor model; security and market risks and benchmarked by the risk-free rate of return.

Where:

$$
[R]=R_{\mathrm{ft}}\left(1-\beta_{\mathrm{j}}\right)+\beta_{\mathrm{j}} \mathrm{R}_{\mathrm{mt}}+\varepsilon_{\mathrm{jt}}
$$

$E[R]$ is the return for security $j$ during period $t$

$\mathrm{R}_{\mathrm{ft}}$ is the risk-free rate of return during period $\mathrm{t}$

$\beta_{\mathrm{j}}$ is the systematic risk of security $\mathrm{j}$ to the market

$\mathrm{R}_{\mathrm{mt}}$ is the return on the market index during period $\mathrm{t}$

$\varepsilon_{\mathrm{jt}}$ is the residual of the equation.

- Standard Deviation

$$
S\left(A R_{i}\right)=\hat{\sigma}_{A R_{i}} \sqrt{1+\frac{1}{M_{i}}+\frac{\left(R_{m, \tau}-\bar{R}_{m, E s t}\right)^{2}}{\sum_{E s t_{\min }}^{E s t_{\max }}\left(R_{m, \tau}-\bar{R}_{M, E s t}\right)^{2}}}
$$

Where: 
$\mathrm{Rm}_{\mathrm{T}_{\mathrm{T}}}$ is the Market return at time $\mathrm{T}$

$\mathrm{Rm}$, Est is the Market return estimated

- Abnormal Return

\subsection{Observation of Ethical Standards}

$$
\mathrm{R}_{\mathrm{AB}}=\mathrm{R}-\mathrm{E}[\mathrm{R}]
$$

According to Resnick, (2015), Research ethics are essential for the reasons that; one, they promote the aims of research; two, they support the values required for collaborative work since the researchers are held accountable for their actions; three, they ensure that the public can trust research and four, they support important social and moral values. Thus, in compliance with ethical consideration, this study obtained consent from respondents and research participants, minimized the risk of harm to participants, protected the anonymity of the respondents, ensured confidentiality of the information obtained, avoided using deceptive practices, gave the respondents and the participants the right to withdraw from the research and finally, obtained a permit from NACOSTI to collect data.

\section{Results and Discussions}

\subsection{Introduction}

This chapter presents results and discussions of the Effects of Earnings Announcements on the Performance of Security Prices of companies listed on the NSE, Kenya.

\subsection{Descriptive Statistics}

In order to test the effect of Earnings Announcements on the Performance of Security Prices on the NSE, Kenya, this study computed the means before and after the announcements and compared them to determine whether there were changes. In addition, this study calculated the standard deviations to establish the spreads from the means.

Table 2. Descriptive statistics

\begin{tabular}{llllll}
\hline & Mean abnormal return & \multicolumn{4}{l}{ Standard Deviation } \\
Before & After & \% Change & Before & After & \% Change \\
\hline 0.1 & 0.01 & -90 & 4.81 & 0.06 & -99 \\
\hline
\end{tabular}

Descriptive Statistics in Table 2 presents mean abnormal return and standard deviation results before and after the Earnings Announcements. The results show mean declined by 90 percent and the standard deviation declined by 99 percent. The decline in mean imply according to the Market Efficiency Hypothesis that the degree of market efficiency was low while low standard deviation suggests that the spread was around the mean.

Table 3. Homogeneity test

\begin{tabular}{llll}
\hline Levene Statistic & df1 & df2 & p-value \\
\hline 3.128 & 1 & 4078 & .077 \\
\hline
\end{tabular}

Table 3 presents the results of the Homogeneity of variances on the Effect of Earning Announcements on the Performance of Security Prices of Companies Listed on NSE, Kenya, using Levene's test. The results show variances were $F(1,4078)=3.128$ and $p$-value $=0.077$ at 5 percent level. Since the $p$-value is insignificant, the Homogeneity assumption is confirmed. 


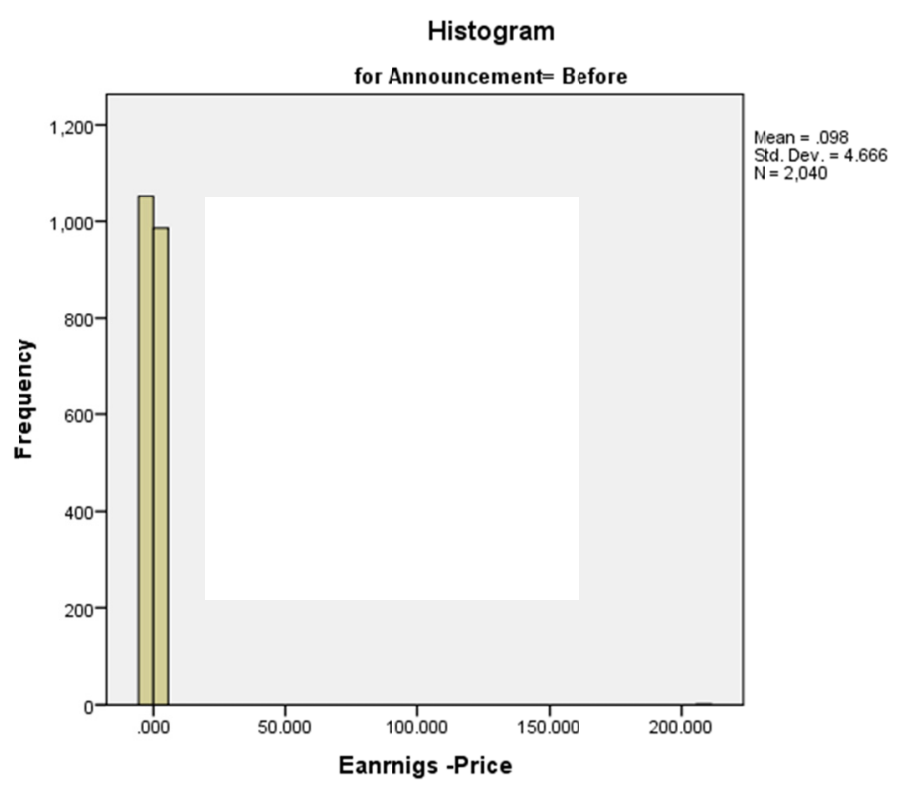

Source: Researcher (2019).

Figure 1. Normality test

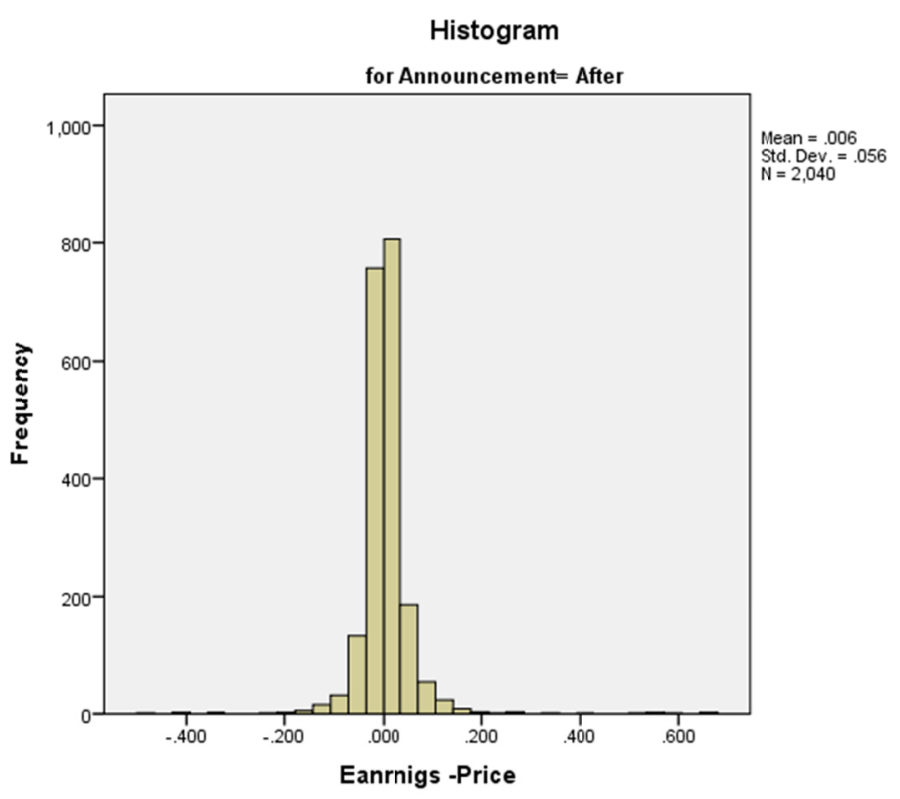

Figure 2. Normality test

Source: Researcher (2019).

Figure 1 and Figure 2 presents the results of the test for Normality. The Histogram in Figure 2 is bell-shaped, thus confirming Normality. Figure 1 seems not to be bell-shaped; thus, violating the Normality assumption. However, the violation of the Normality assumption, according to Pallant (2007), should not cause major problems with large sample size as is in this study. As such, according to Elliott (2007), this study can use parametric procedures even when the Normality tests are violated. Hence, this study ignores the violation. 
Table 4. Significance test on the earnings announcements and the securities prices

\begin{tabular}{llllll}
\hline & Sum of Squares & df & Mean Square & F & p-value. \\
\hline Between Groups & 8.645 & 1 & 8.645 & .794 & .373 \\
Within Groups & 44400.429 & 4078 & 10.888 & & \\
Total & 44409.075 & 4079 & & & \\
\hline
\end{tabular}

This study formulated null-hypothesis Ho that the Effect of Earning Announcements on the Performance of Securities of companies listed on the NSE, Kenya was not significant. As such, this study tested the null-hypothesis using the ANOVA technique at 5 percent level as presented in Table 4. The results of the ANOVA test in the table show p-value $=.373$, implying the effect of Earning Announcements on the Performance of Security Prices is statistically insignificant. This indicates that the Earning Announcements were within the market expectation, hence did not trigger price changes. According to Aswath (2012), it is not the magnitude of the earnings change that matter, but the "surprise" in the earnings, measured as the earnings change relative to expectations. As such, when a company announces its earnings, markets will react to the "news" in the announcement, but the way the news is measured has to be relative to expectations. Under the Market Expectation Theory, security prices tend to rise when earnings results exceed market expectations and decline when earnings results are below market expectation. In this study, descriptive statistics in Table 2 show a decline in the mean abnormal return by 90 percent, implying that the decline was within the market expectation.

Similarly, statistical insignificance demonstrated in this study, according to Regnault (1863), is attributed to the market being efficient in weak-form. This suggests that security prices reflected all the data on past prices and true value.The implication is that the security exchange is efficient at the informational level of the weak-form. As such, the security prices of companies listed on the NSE, Kenya incorporated all available information at the time of the Earnings Announcements. However, a rise in the mean abnormal return, as shown in the Descriptive Statistics results in Table 2 contradict Regnault (1863) theory. According to Regnault (1863), the market is efficient in weak-form if investors cannot obtain abnormal returns by analyzing relevant historical information about the securities, rendering investment tools like filter strategy, technical analysis to be ineffective.

This finding is inconsistent with the findings of Mohamed (2011). Mohamed, (2011) who studied the Effect of the Earnings Announcements on the stock prices of companies listed on the Nairobi Stock Exchange, observed statistically negative abnormal returns in the post and pre-announcement. The inconsistency between Mohamed, (2011) and this study is due to methodologies used. Shireen and Kavita (2016) found an increase in the share price that resulted in positive average abnormal return, especially in the post-dividend. The inconsistency between Shireen and Kavita (2016)'s study, and this study lies in the size of the sample used (21 companies vis-à-vis 25 companies in this study). Sanjay and Bijoy Kumar (2015) examined the stock price reaction around Earnings Announcement in India in 469 sampled companies using event study methodology and observed a large part of abnormal returns and a significant post-event abnormal return. The inconsistency between Sanjay and Bijoy Kumar (2015)'s and this study is due to the size of the sample (469 companies against 25 companies in this study) and the locations of the studies (India vis-a-vis Kenya). Lyimo (2014) examined the relationship between stock price synchronicity and earnings quality and used earning surprise and smoothness as a proxy of earnings quality, from companies listed in Bombay Stock Exchange in BSE 500, from 2006 to 2012. The study employed a panel data regression model using pooled ordinary least squares (OLS) with standard error robust. The study found that there was a significant negative relationship between earnings surprise and stock price synchronicity. The inconsistency between Lyimo (2014)'s study, and this study lies in the methodologies used, the locations of the studies, and the objectives of the studies. Yakubu, Akuoko, and Esumanba (2013) examined the effects of corporate Earnings Announcement on the Ghana Stock Exchange (GSE), using a sample of 19 Company Listed, selected from 57 observations of Earnings Announcements from 2009 to 2012, using event study methodology. The study concluded that earnings announcements do convey information to the market of which investors react accordingly. The inconsistency between Yakubu, Akuoko, and Esumanba (2013)'s and this study lies on the dissimilarity of the objective of the studies.

On the other hand, this study is consistent with the findings of Olang and Akenga (2017) on the Effect of Earnings Announcement on Share Prices of Companies listed on the Nairobi Securities Exchange, using Event study Methodology, correlation analysis, and t-statistics. The study found that abnormal returns around the earnings announcements date were insignificant at 5 percent level. Though the techniques used and the sample sizes differ. Kiremu, Galo, Wagala, and Mutegi (2013), studied Stock Price and Volumes Reaction to Annual Earnings Announcement: at the Nairobi Securities Exchange using Event Study Methodology on 58 Company 
Listed with event window of 91 days. The study found abnormal returns and TAR were not significant at 5 percent level.

\section{Summary and Conclusions}

\subsection{Summary of the Findings}

This study examined the effects of Earnings Announcements on the Performance of Security Prices of Companies Listed on the Nairobi Securities Exchange, Kenya.

The study collected data from 25 companies listed on the Nairobi Securities Exchange, analyzed using the Event Study Methodology and the ANOVA technique. The study revealed insignificant result.

\subsection{Findings on the Effect of Earnings Announcements on the Performance of Securities Prices of Companies} Listed on the NSE, Kenya

This study formulated a hypothesis that the "Earnings Announcements has no significant effect on the Performance of Security Prices of company listed on the NSE, Kenya." The Study tested the hypothesis and found that the effect of Earnings Announcements on the Performance of Security Prices did not have significant effect on the Performance of Security Prices. The Study was conducted at 5 percent significant level, and gave a p-value of 0.373 .

\subsection{Conclusions}

Based on the findings of the study, the study concludes that Earnings Announcement did not have effects on the Performances of Security Prices. This is demonstrated by significance tests yielding p-value greater than 5 percent significant level.

This result could be due to the size of companies studied, the estimation of the event window or the technique used. Since the study objectives did not yield statistically significant results, this study concludes that the Null hypothesis was, in fact, true.

\subsection{Recommendations}

Based on the data, the factors, and the methodology used in this study, and since there are many prior studies in this area, the finding of this study indicates possible directions for future research. As the study has revealed, there are some similarities, differences, and results that may not have been covered, and, which may be useful for companies listed or not listed on the NSE, Kenya. Future research should investigate specific companies that were affected by the decline in security prices and companies listed on other security exchanges with similar problem(s) in order to generalize the findings.

Further, this study recommends that: companies listed on the NSE, Kenya, to be encouraged to date their financial statements and other documents. Dating of records and the financial statements will provide the regulator, investors, the market players, and the public with the date when the financial statements were approved and corporate action made. Finally, the regulator should strengthen regulations. This will ensure compliance with insider trading laws by market players hence improve market efficiency and build investors and public confidence, establish relevant policies to enhance the efficiency of the securities exchange.

\section{References}

Aharony, J., \& Swary, I. (1980). Quarterly Dividend and Earnings Announcements and Stockholders' Return: An Empirical Analysis. The Journal of Finance, 35(1), 1-12. https://doi.org/10.1111/j.1540-6261.1980.tb03466.x

Aswath, D. (2012). Investment Valuation: Tools and Techniques for determining the Value of Any Asset (3rd ed.). John Wiley and Sons.

Bernanke, B., \& Gertler, M. (1989). Agency Costs, Net Worth, and Business Fluctuations. The American Economic Review, 79(1), 14-31.

Boyes, W. (2011). Managerial Economics: Market and the Firm (2nd ed.). Cengage Learning. South -Western. Retrieved from https://books.google.co.ke/books?isbn=1133417108

Capital Markets (Securities). (2002). Fifth Schedule. (Public Offers, Listing and Disclosures) Regulation. Nairobi. The Government Printer.

Elliott, A. C., \& Woodward, W. A. (2007). Statistical analysis quick reference guidebook with SPSS examples (1st ed.). London: Sage Publications. https://doi.org/10.4135/9781412985949 
Fama, E. F. (1970). Efficient Capital Markets: A Review of Theory and Empirical work. Journal of Finance 25, 383-417. https://doi.org/10.2307/2325486

Fama, E. F., Fisher, L., Jensen, M. C., \& Roll, R. (1969). The Adjustment of Stock Prices to New Information. International Economic Review, 10, 1-21. https://doi.org/10.2307/2525569

Gordon, M. J. (1959). Dividends, Earnings and Stock Prices. Review of Economics and Statistics, 41(2), 99-105. https://doi.org/10.2307/1927792

Gordon, M. J. (1962). The investment, Financing and Valuation of Corporation. Richard D. Irvin.

Kelikume, I. (2016). New evidence from the efficient market hypothesis for the Nigerian stock index using the wavelet unit root test approach. The Journal of Developing Areas, 50(5), 185-197. https://doi.org/10.1353/jda.2016.0041

Kiremu, K. G., Galo, N., Wagala, A., \& Mutegi, J. K. (2013). Stock Price and Volumes Reaction to Annual Earnings Announcement: A Case of the Nairobi Securities Exchange. International Journal of Business, Humanities and Technology, 3(2).

Kiyotaki \& Moore. (1997). Credit Cycles. Journal Article Journal of Political Economy, 105(2), 211-248. https://doi.org/10.1086/262072

Lintner, J. (1962). Dividends, Earnings, Leverage, Stock Prices and the Supply of Capital to Corporations. The Review of Economics and Statistics, 243-269. https://doi.org/10.2307/1926397

Luke, Q. (2015). Earnings Announcement and Abnormal Return of S\&P 500 Companies. Retrieved from https://economics.wustl.edu/files/economics/imce/luke_qiu__final.pdf

Lyimo, G. D. (2014). Smoothness, Earnings Surprise and Stock Price Informativeness. Evidence from Indian Stock Market. International Journal of Academic Research in Accounting, Finance and Management Sciences 4, 385-394.

Macionis, J. J., \& Gerber, L. M. (2010). Sociology, Seventh Canadian Edition. Pearson Education, Canada.

Markowitz, H. (1952). Portfolio Selection. The Journal of Finance 7(1), 77-91. https://doi.org/10.1111/j.1540-6261.1952.tb01525.x

Modigliani, F., \& Miller, M. H. (1961). Dividend Policy, Growth and Valuation of the Shares. Journal of Business, 411-433. https://doi.org/10.1086/294442

Mohamed, H. M. (2011). The Effect of the Earnings Announcements on the Stock Prices of Companies Listed on the Nairobi Stock Exchange. Retrieved from http://erepository.uonbi.ac.ke:8080/bitstream/handle/11295/14495/Mohamed_The\%20effect\%20of\%20the $\% 20$ earnings $\% 20$ announcements $\% 20$ on $\% 20$ the $\% 20$ stock $\% 20$ prices.pdf? sequence $=3 \&$ is Allowed $=y$

Mossin, J. (1966). Equilibrium in a Capital Asset Market. Econometrica, 34(2), 768-83. https://doi.org/10.2307/1910098

Muga, J. A (2014). An Investigation of the Effect of Announcement of Earnings and Dividend on Price and Volume for Listed Non-Financial Firms at the NSE for the Period 2010-2013.

MyStocks. (2018). Online Historical security Prices.

NSE (2018): Review of The NSE 20 and 25 Share Index Constituent Counters. https://www.nse.co.ke/inverstorrelations/2-uncategorised/123-nse-handbook.html

Olang, M. A., \& Akenga, G. M. (2017). Effect of Earnings Announcement on Share Prices of Companies Listed at the Nairobi Securities Exchange. European Business \& Management, 3(2), 29-36. https://doi.org/10.11648/j.ebm.20170302.13

Owusu, F., Gyau, E. K., \& Amaning, N. (2016). The Effect of Earnings Announcement on Share Price of Manufacturing Companies on the Ghana Stock Exchange. European Journal of Accounting, Auditing and Finance Research, 4(6), 96-111.

Pallant J. (2007). SPSS survival manual, a step by step guide to data analysis using SPSS for windows (3rd ed.). Sydney: McGraw Hill.

Pearce, D. K. (1983). Stock Prices and the Economy. Economic Review - Federal Reserve Bank of Kansas City.

Pettit, R. R. (1976). The Impact of Dividend and Earnings Announcements: A Reconciliation. The Journal of Business, 49(1), 86-96. https://doi.org/10.1086/295813 
Poitras, G. (2011). Valuation of Securities: Philosophy, History and Application. World Scientific Publishing Co. Singapore. https://doi.org/10.1142/7633

Regnault, J. (1863). Calcul des Chances et Philosophie de la Bourse, Mallet-Bachelier et Castel, Paris.

Ross, S. A. (1977). The Determination of Financial Structure: The Incentive-Signaling Approach. Bell Journal of Economics, 8(1), 23-40. https://doi.org/10.2307/3003485

Sanjay, S., \& Kumar, B. (2015). Stock Price Reactions to Earnings Announcements. Retrieved from http://journals.sagepub.com/doi/abs/10.1177/0972262914564042

Schwert G. W. (1981) Using Financial Data to Measure Effects of Regulation. Journal of Law and Economics, 24, 121-158. https://doi.org/10.1086/466977

Sharpe, W. F. (1964). Capital Asset Prices: A Theory of Market Equilibrium under Conditions of Risk. The Journal of American Finance Association. https://doi.org/10.2307/2977928

Shireen, R., \& Kavita, C. (2016). Market Reaction on Dividend Announcement in Oman: An Event Study Methodology. International Journal of Economics and Financial Issues, 6(1), 103-108.

Shireen, R., \& Kavita, C. (2016). Market Reaction on Dividend Announcement in Oman. International Journal of Economics and Financial Issues, 6(1), 103-108.

Silva, P. P. (2016). Earnings surprises and the response of CDS markets, Studies in Economics and Finance. Emerald Insight Journal, 33(3), 377-402. https://doi.org/10.1108/SEF-11-2014-02

Sunjoo, B., \& Erika, S. F. (2013). Secondary analysis of national survey datasets. Japan Journal of Nursing Science, 10, 130-135. https://doi.org/10.1111/j.1742-7924.2012.00213.x

Treynor, J. L. (2012). Toward a Theory of Market Value of Risky Assets. Treynor on Institutional Investing. https://doi.org/10.1002/9781119196679.ch6

Treynor, J. L. (2012). How to Rate Management of Investment Funds. Treynor on Institutional Investing. https://doi.org/10.1002/9781119196679.ch10

Watts, R. (1973). The Information Content of Dividends. The Journal of Business, 46(2), 191-211. https://doi.org/10.1086/295525

Werner, M. (2018). Study on Dividend Policy: Antecedent and Its Impact on Share. SSRN Electronic Journal October 2010. Price. https://doi.org/10.2139/ssrn.1686109

Yakubu, A. S., Akuoko, S., \& Esumanba, V. (2013). Effects of Earnings Announcement on Share Price: The Case of Ghana Stock Exchange. International Journal of Research in Social Sciences, 2(4).

\section{Copyrights}

Copyright for this article is retained by the author(s), with first publication rights granted to the journal.

This is an open-access article distributed under the terms and conditions of the Creative Commons Attribution license (http://creativecommons.org/licenses/by/4.0/). 